EISSN: 2706-7955 ISSN: 2077-4605

DOI: $10.36632 / \mathrm{mejar} / 2021.10 .1 .15$

Journal homepage: www.curresweb.com

Pages: 256-261

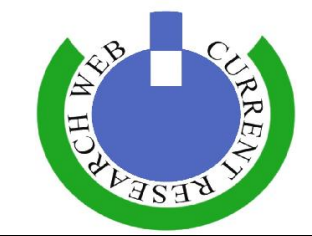

\title{
An Analytical Study of the Current Status of Fish and Spending on it in Fayoum Governorate (A Case Study of Fayoum Governorate)
}

\author{
Yehia M.M. Khalil, Fatima A. Shafiq, Nagwa M. El-Agroudy and Monia B. El-Din \\ Hassan
}

Department of Agricultural Economy, Agricultural and Biological Research Division, National Research Centre, 33 El Buhouth St., 12622 Dokki, Giza, Egypt

Received: 25 December 2020 Accepted: 20 February 2021 Published: 10 March 2021

\begin{abstract}
Animal protein is conspicuously one of the most important components of food because it contains amino acids that the body cannot make or replace what is lost from them. Its importance is because it helps to grow and compensate for what is lost from the body. Despite this importance of animal protein, the average annual per capita share in Egypt is lower than the preventive limit recommended by the Food and Agriculture Organization (FAO) and the World Health Organization. The problem was conspicuously represented in the inability of the local production of fish protein and its failure to keep up with the increasing demand for it, and the increasing population. Moreover, the study aims to study the status of protein production from poultry and fish in Egypt and its most important economic indicators during the period (2000-2018) and to study the spending function of the study sample at different income levels. Besides, the study was based on secondary data collected from The Central Agency for Public Mobilization and Statistics and the Ministry of Agriculture. It also relied mainly on the preliminary data collected through the questionnaire form for a random sample of 312 families from Fayoum Governorate and distributed as follows: 147 families from the urban of Fayoum Center and 165 families from the rural of Fayoum Center in 2019. The study revealed the statistically significant increase in both production and consumption of fish and the insignificant decrease in the average of fish per capita by about $64.986,63.705$ tons / year, $1.65 . \mathrm{Kg}$ / year, respectively. Moreover, the study showed an increase in the self-sufficiency rate of fish, which amounted to about $0.711 \%$. It is also show by the study of the consumption spending on fish in the three categories of the study sample that there is a statistically positive relationship between spending on fish and between the numbers of family members. The price of red meat and the price of poultry in urban areas of the governorate for the first and second categories. There is also a statistically significant positive relationship between consumption spending, monthly income and the number of family members in the third category. As for the governorate rural, there is a statistically direct, significant relationship between the spending, the number of family members, the price of red meat and poultry, and inversely with the price of fish in the first category. As for the second category, there is a direct relationship between the consumption of fish and the number of family members and an inverse relationship with the price of fish, the number of family members, the income of the consumer, and an inverse relationship with the price of fish.
\end{abstract}

Keywords: Consumer Spending - Fish - Spending Flexibility

\section{Introduction}

Fish is conspicuously considered an important source of food sources needed to build the human body, where fish protein is highly characterized by easily digestion and absorption compared to the protein found in red meat and poultry meat. This is in addition to containing fatty acids needed to protect the human body from many diseases. Moreover, fish production is considered one of the basic components of animal production, which in turn is considered one of the two parts of agricultural

Corresponding Author: Yehia M.M. Khalil, Department of Agricultural Economy, Agricultural and Biological Research Division, National Research Centre, 33 El Buhouth St., 12622 Dokki, Giza, Egypt 
production. Fish production contributes by about 21.06 billion pounds, representing about $42.55 \%$ of the value of net animal income, which amounted to about 49.46 billion pounds, and about $9.55 \%$ of the total value of net agricultural income. This is approximately 218.2 billion pounds as in the average period (2012 - 2016). Besides, development of fish production is considered one of the main pillars of the development of animal protein in the Republic of Egypt. However, Egypt suffers from a deficiency in the production of animal protein and low average per capita compared to the world average. The world average per capita of animal protein is about $27.5 \mathrm{~kg}$ per year, while it has not amounted in Egypt to half of that rate. That is why the development of fish production is considered one of the pillars of the development of animal protein sources in Egypt., As Egyptian fish production increased from about 649 thousand tons in 2000 to about 1870 thousand tons in 2018 with an increase of about $188 \%$ and with an average production of about 1205.2 thousand tons during the period 2000-2018.

\section{Problem of the Study}

The problem is conspicuously represented in the inability of the local production of fish protein and its failure to keep up with the increasing demand for it, which resulted in the existence of a food gap of protein by about 177.7 thousand tons. Moreover, the local production of fish cannot meet the requirements of local consumption. Besides the percentage of fish, self-sufficiency in Egypt increased from about $73 \%$ in 2000 to about $94.4 \%$ in 2018. If it were not for the efforts made by the state in this field represented in fish farming projects, the self-sufficiency ratio would have decreased, which negatively affects prices, the average per capita share of the commodity, and the imbalance in commercial performance along with an increase in the burden on the balance of payments and the country's trade balance.

\section{Objective of the Study}

The research aims to study the status of fish production in Egypt and the most important economic indicators for it during the period (2000-2018). Besides, it examines the spending function of the study sample at different income levels.

\section{Methodology of the Study and Data Sources}

The study used the descriptive analysis approach in describing the problem. This is in addition to the quantitative analysis using some different scales such as the general trend that was used in studying the development of some production and consumption indicators of the commodity under study, as well as the multiple regression that was used in estimating each of the spending functions of the study sample.

The study obviously depended on secondary data collected from the Central Agency for Public Mobilization and Statistics and the Ministry of Agriculture. It also relied mainly on the primary data that was collected through a questionnaire form for a random sample of 312 families from Fayoum Governorate distributed as follows: 147 families from the urban of Fayoum Center and 165 families from the rural of Fayoum Center in 2019.

\section{Results of the Study}

\section{The Development of some Indicators of Fish Production in Egypt First: Development of Fish Production in Egypt}

The data shown in Table No. (1) Related to the development of fish production capacity in Egypt indicates a gradual, large and clear increase in fish production during the period (2000-2018). It ranges between two limits: a minimum amounting to about 649 thousand tons in 2000 and a maximum amount to about 1870 thousand tons in 2018 with an increase of $188.1 \%$ compared to its counterpart in 2000 . Besides, the average size of the fish gap during the study period was estimated at 117.7 thousand tons, with an average of self-sufficiency rate estimated at $86.5 \%$ during the study period.

Equation No. (1) In Table No. (2) Also clarifies that production took a general, increasing annual and statistically significant trend, amounting to about 64.986 thousand tons, representing about $5 \%$ of the study period average. 


\section{Second: Evolution of fish consumption in Egypt}

Table No. (1) shows a gradual increase in fish consumption, as consumption ranged between two limits, a minimum amounting to about 886 and a maximum amount to about 1980 thousand tons in the years 2000-2018 respectively. It was with an increase of about 123.5 in relation to its counterpart in 2000. Moreover, equation No. (2) In Table No. (2) Obviously illustrates that consumption took a general, annually and statistically significant, increasing trend, reaching about 63,705 thousand tons, representing about $4.62 \%$ of the study period average.

\section{Third: Evolution of the Average per Capita of Fish in Egypt}

Table No. (1) Shows a gradual decrease in the average per capita share of fish, as consumption ranged between two limits, a minimum amounting to about 12.2 and a maximum amount to about 16.6 $\mathrm{kg} /$ year in 2010 and 2007 respectively. Besides, the average of the study period amounted to about $14.04 \mathrm{~kg}$ / year. Moreover, equation (3) in Table (2) shows that the average per capita has taken a general annual, declining and statistically significant trend, reaching about $1.65 \mathrm{~kg} /$ year, representing about $11.75 \%$ of the study period average.

\section{Fourth: Evolution of the Self-sufficiency Rate of Fish in Egypt}

Table No. (1) Shows a gradual increase in the self-sufficiency rate of fish, as the ratio ranged between two limits, a minimum amounting to about $73 \%$ and a maximum amount to about $94.4 \%$ in the years 2000 and 2018, respectively. Besides, equation (4) in Table (2) shows that the percentage of selfsufficiency in fish has taken a general, annually, increasing and statistically significant trend, reaching about $0.711 \%$ annually, representing about $0.82 \%$ of the study period average.

Table 1: Development of some production and consumption indicators for fish in the Arab Republic of

\begin{tabular}{cccccc}
\multicolumn{2}{c}{ Egypt during the period (2000-2018) } & & & \\
\hline Year & $\begin{array}{c}\text { Production } \\
\text { (Thousand tons }\end{array}$ & $\begin{array}{c}\text { Consumption } \\
\text { (Thousand tons }\end{array}$ & Per capita/kg & $\begin{array}{c}\text { \% Self- } \\
\text { sufficiency }\end{array}$ & $\begin{array}{c}\text { The food gap } \\
\text { (Thousand tons) }\end{array}$ \\
\hline $\mathbf{2 0 0 0}$ & 649 & 886 & 14 & 73 & 237 \\
$\mathbf{2 0 0 1}$ & 772 & 950 & 14.5 & 81.3 & -178 \\
$\mathbf{2 0 0 2}$ & 801 & 932 & 13.9 & 86.8 & -122 \\
$\mathbf{2 0 0 3}$ & 876 & 1015 & 14.9 & 86.3 & -139 \\
$\mathbf{2 0 0 4}$ & 865 & 1064 & 15.3 & 81.3 & -199 \\
$\mathbf{2 0 0 5}$ & 889 & 1075 & 15.2 & 82.7 & -186 \\
$\mathbf{2 0 0 6}$ & 971 & 1173 & 16.2 & 82.8 & -202 \\
$\mathbf{2 0 0 7}$ & 1008 & 1225 & 16.6 & 82.3 & -217 \\
$\mathbf{2 0 0 8}$ & 1085 & 1151 & 15.3 & 94.3 & -66 \\
$\mathbf{2 0 0 9}$ & 1093 & 1264 & 16.5 & 86.5 & -171 \\
$\mathbf{2 0 1 0}$ & 1305 & 1481 & 12.2 & 88.1 & -176 \\
$\mathbf{2 0 1 1}$ & 1362 & 1526 & 12.3 & 89.3 & -164 \\
$\mathbf{2 0 1 2}$ & 1372 & 1605 & 12.6 & 85.5 & -233 \\
$\mathbf{2 0 1 3}$ & 1454 & 1653 & 12.6 & 88.9 & -181 \\
$\mathbf{2 0 1 4}$ & 1482 & 1704 & 12.8 & 87 & -222 \\
$\mathbf{2 0 1 5}$ & 1519 & 1707 & 12.5 & 89 & -188 \\
$\mathbf{2 0 1 6}$ & 1706 & 1894 & 13.5 & 90.1 & -188 \\
$\mathbf{2 0 1 7}$ & 1820 & 1930 & 12.8 & 94.3 & -110 \\
$\mathbf{2 0 1 8}$ & 1870 & 1980 & 12.6 & 94.4 & -110 \\
\hline Average & 1205.2 & 1379 & 14.04 & 86.5 & -173.3 \\
\hline
\end{tabular}

Food gap = production-consumption.

Self-sufficiency $=($ production $/$ consumption $) \times 100$

Source: Central Agency for Public Mobilization and Statistics, annual bulletins of livestock statistics - Various

\section{Fifth: Evolution of the Food Gap of Fish in Egypt}

Table No. (1) Shows a gradual increase in the amount for the fish gap, as it ranged between two limits, a minimum amounting to about 66 thousand tons in 2008 and a maximum amount to about 370 thousand tons in 2011, with an increase of about $460.6 \%$ relative to its counterpart in 2008. Besides, equation No. (5) In Table No. (2), shows that the fish gap has taken a general, annually, declining, 
statistically insignificant, trend, reaching about 1.296 thousand tons and representing about $0.75 \%$ of the study period average.

Table 2: General time trend equations for fish production and consumption indicators in Egypt during the period (2000-2018)

\begin{tabular}{lllccc}
\hline Equation number & The dependent variable & Equation & $\mathbf{T}$ & $\mathbf{F}$ & $\mathbf{R}$ \\
\hline $\mathbf{1}$ & Production quantity & $\mathrm{Y}^{\wedge} \mathrm{i}=555.351+64.986 \mathrm{Xi}$ & $25.484^{* *}$ & 600.47 & 0.974 \\
$\mathbf{2}$ & Consumption quantity & $\mathrm{Y}^{\wedge} \mathrm{i}=742.684+63.705 \mathrm{Xi}$ & $23.614^{* *}$ & 557.63 & 0.985 \\
$\mathbf{3}$ & Per capita consumption & $\mathrm{Y}^{\wedge} \mathrm{i}=15.637-1.65 \mathrm{Xi}$ & $-2.936^{*}$ & 9.690 & $0 . .580$ \\
$\mathbf{4}$ & \% Self-sufficiency & $\mathrm{Y}^{\wedge} \mathrm{i}=-79.414+0.711 \mathrm{Xi}$ & $4.771^{* *}$ & 22.762 & 0.757 \\
$\mathbf{5}$ & The food gap & $\mathrm{Y}^{\wedge} \mathrm{i}=-186.070-1.296 \mathrm{Xi}$ & 0.668 & 0.446 & 0.468 \\
\hline
\end{tabular}

Where $\mathrm{Y}^{\wedge}$ indicates the estimated value of the dependent variable $\mathrm{x}_{\mathrm{e}}$

Indicates the element of time as an independent variable, where e $(1,2,3,4 \ldots \ldots .19)$.

** Significant at the level of $1 \%$

* Significant at the level of 5\%

Source: calculated from table (1).

Per Capita Consumption and Spending on Fish of the Study Sample

The per capita monthly consumption of fish in the urban first category of the study sample was about $1.083 \mathrm{~kg} /$ month, while in the rural it was about $0.833 \mathrm{~kg} /$ month. Consequently, the increase in the urban population over the rural represents about $30 \%$. Moreover, the share of the individual of fish per month in the urban second category of the study sample is about $1.500 \mathrm{~kg} / \mathrm{month}$, while in the rural it is about $1.083 \mathrm{~kg} /$ month. Thus, the increase in urban areas over the rural e represents about $38.5 \%$. It is clear from the data of Table No. (3) That the per capita monthly consumption of fish for the third category of fish in the urban sample is about $1.833 \mathrm{~kg} /$ month, while it is about $1.583 \mathrm{~kg} /$ month in the rural. Therefore, the increase in urban areas over the rural is about $15.8 \%$. As for prices, their convergence in urban and rural areas has become evident, but it is difficult for the first category to obtain fresh fish, so most individuals consume frozen fish at prices commensurate with their income.

Moreover, Table No. (3) Shows the household's monthly spending of fish in the urban sample of the first category, which amounts to about 162.5 pounds / month, while in the rural it is about 145.8 pounds / month. The increase of the urban population over the rural represents about $11.4 \%$ for fish. However, the monthly spending of the urban population in the second category is estimating at about 300 pounds / month while in the rural it is about 227.5 pounds / month. Besides, the increase in urban areas over the rural represents about $31.9 \%$, while it is evident that the monthly spending on fish in the third category is about 366.7 pounds / month. Additionally, it is about 316.7 pounds / month in the rural and the increase for the urbanites over the rural is about $15.8 \%$.

Table 3: The selected sample in the urban and rural Fayoum, per capita consumption, consumer prices, household income, and monthly expenditures on fish (2019)

\begin{tabular}{lcccccc}
\hline Statement & \multicolumn{2}{c}{ First category } & \multicolumn{2}{c}{ Second category } & \multicolumn{2}{c}{ Third category } \\
\cline { 2 - 7 } & Urban & Rural & Urban & Rural & Urban & Rural \\
\hline Number of families & 30 & 35 & 80 & 85 & 37 & 45 \\
Number of family members & 5 & 7 & 5 & 6 & 4 & 5 \\
The family income monthly & 1853 & 1537 & 3670 & 3150 & 6550 & 5218 \\
Per capita kg/month & 1.083 & 0.833 & 1.500 & 1.083 & 1.833 & 1.583 \\
Total meat kg / year & 2.917 & 2.417 & 4.250 & 3.417 & 5.500 & 4.750 \\
The price of fish kg / pounds & 30 & 25 & 40 & 35 & 50 & 40 \\
Spending on fish/pound & 162.5 & 145.8 & 300 & 227.5 & 366.7 & 316.7 \\
Total spend /pound & 716.3 & 686 & 1214.6 & 1127.5 & 1463.3 & 1339.6 \\
\hline
\end{tabular}

Source: collected and calculated from the data of the study sample in Fayoum Governorate in (2019).

\section{Factors Affecting Consumer Spending in Urban and Rural Areas of the Sample:}

Through studying the relationship between the consumption spending of meat (y) as a dependent factor, and the independent and influential factors. These are the number of family members (x1), the price of red meat (x2), the price of poultry (x3), the price of fish (x4), and the monthly income of the head of the family (x5). The income, the price of the commodity and the prices of substitute commodities were used for each type of meat, whether red meat, poultry or fish. Besides, the stepwise regression was 
use in the double logarithmic form to determine the most important factors affecting spending on fish in the study sample in urban and rural areas of Fayoum for different income groups.

\section{Consumption Spending on Fish in Urban and Rural Areas of the Three Categories of the Study Sample}

It is important to mention in this context that the estimates of the function shown in Table No. (4) Refer to the statistically positive and significant relationship between the monthly spending on fish meat in the first category at urban of Fayoum governorat (less than 2000 pounds) in the study sample and the number of family members (x1), and the price per kilogram of red meat (x2). This is in addition to the price per kilogram of poultry meat (x3), where the spending flexibility was estimate at about 1.1, 0.81 and 0.19 , respectively. This means that spending on fish increases with the increase in the number of family members and the price of a kilogram of red meat, and the price per kilogram of poultry meat.

Table 4: Regression equations for the most on fish in the urban and rural areas of Fayoum governorate in the three important factors affecting spending study categories in (2019)

\begin{tabular}{|c|c|c|c|c|c|}
\hline Categories & & & Equation & $\mathbf{R}$ & F \\
\hline \multirow{2}{*}{$\begin{array}{l}\text { First } \\
\text { category }\end{array}$} & 1 & Urban & $\begin{array}{ccc}\mathrm{LNY}^{\wedge}=6.7+1.1 \mathrm{LNX} 1 \mathrm{i}+0.810 \mathrm{LNX} 2 \mathrm{i}+0.19 \mathrm{LNX} 3 \mathrm{i} \\
(5.9)^{* *} & (2)^{*} & (2.3)^{* *}\end{array}$ & 0.57 & 16 \\
\hline & 2 & Rural & 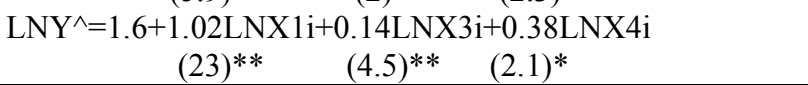 & 0.93 & 284 \\
\hline \multirow{2}{*}{$\begin{array}{l}\text { Second } \\
\text { category }\end{array}$} & 3 & Urban & $\begin{array}{l}\mathrm{LNY}^{\wedge}=2.9+0.971 \mathrm{LNX} 1+0.430 \mathrm{LNX} 2-0.617 \mathrm{LNX} 4 \mathrm{i} \\
\begin{array}{ccc}(2)^{*} & (2)^{*} & (11)^{* *}\end{array}\end{array}$ & 0.57 & 47 \\
\hline & 4 & Rural & $\begin{array}{c}\mathrm{LNY} \mathrm{C}^{\wedge}=2.28+0.824 \mathrm{LNX} 1 \mathrm{i}-0.448 \mathrm{LNX} 2 \mathrm{i} \\
(15)^{* *} \quad(4.4)^{* *}\end{array}$ & 0.61 & 119 \\
\hline \multirow{2}{*}{$\begin{array}{l}\text { Third } \\
\text { category }\end{array}$} & 5 & Urban & $\begin{array}{c}\mathrm{LNY}^{\wedge}=0.910+0.676 \mathrm{LNX} 1 \mathrm{i}+ \\
(2.9)^{* *} \\
0.578 \mathrm{LNX} 5 \mathrm{i} \\
(3)^{* *}\end{array}$ & 0.40 & 8.1 \\
\hline & 6 & Rural & 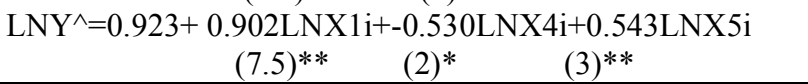 & 0.71 & 21.4 \\
\hline
\end{tabular}

Where: $\mathrm{Y}^{\wedge} \mathrm{i}$ : the estimated value of the monthly expenditure on meat in pounds (red meat, fish, and poultry).

X1i: number of family members

$\mathrm{X} 2 \mathrm{i}$ : The price per kilogram of red meat in pounds

$\mathrm{X} 3 \mathrm{i}$ : the price per kilogram of poultry meat

$\mathrm{X} 4 \mathrm{i}$ : The price of a kilogram of fish meat in pounds

$\mathrm{X} 5 \mathrm{i}$ : Average household monthly income in pounds

$(* *)$ significant at 0.01 level of significance, $\left(^{*}\right)$ significant at 0.05 level of significance, the value in parentheses indicates the value of (calculated T).

Source: collected and calculated from the data of the study sample in Fayoum Governorate in 2019.

As for the rural of the first category of the study sample (less than 2000 pounds), the estimates of the function shown in the same table indicate the statistically positive and significant relationship between the monthly spending on fish meat in the countryside of the first category of the study sample in Fayoum, the number of family members (x1), the price per kilogram of red meat (x2) and the price per kilogram of poultry (x3). Besides, the spending flexibility was estimate at about $1.02,0.14$, and 0.38 , respectively. Consequently, this means that spending on fish meat increases with the increase in the number of family members, the price per kilogram of red meat and the price per kilogram of poultry.

The function estimates shown in Table No. (4) Indicate the statistically positive and significant relationship between the monthly spending on fish meat in the second category at urban (2000-4000 pounds) in the sample of the study, the number of family members (x1), and the price per kilogram of poultry meat (x3). Moreover, the spending flexibility was estimate at about 0.971 and 0.430 , respectively. Which means that spending on fish increases with the increase in the number of family members and the price per kilogram of poultry meat, while the inverse relationship between spending on fish meat and the price of a kilogram of fish meat $(\mathrm{x} 4)$ was evident where the spending flexibility reached about 0.617 .

As for the rural of the second category of the study sample (2000-4000 pounds), the estimates of the function shown in Table (4) indicate the statistically positive and significant relationship between the monthly spending on fish meat and the number of family members (x1). Besides, the spending flexibility was estimate at about 0.824 . Thus, it means an increase of spending on fish by increasing the 
number of family members, while the inverse relationship between spending on fish meat and the price of one kilogram of fish meat was clear, as the spending flexibility reached bout 0.448 .

Moreover, the explained equation estimates refer to the statistically positive and significant relationship between the monthly spending on fish meat in the third category at urban (4000 pounds or more) in the study sample and the number of family members (x1), along with the monthly income per pounds (x5), where the spending flexibility was estimated at 0.676 and 0.578 , respectively. Thus, it means that spending on fish increases with the number of family members and monthly income.

As for the rural of the third category of the study sample ( 4000 pounds or more). The estimates of the equation shown in Table (4) indicate the statistically positive and significant relationship between the monthly spending on fish meat and the number of family members $(1 \mathrm{x})$, along with the monthly income (x5), where the spending flexibility was estimated by about 0.902 and 0.543 , respectively. Thus, it means that the spending on fish increases with the increase in the number of family members and the monthly income of the family, while the inverse relationship between spending on fish and the price of fish has been shown, meaning that with the decrease in the price of fish, the spending on it increases.

\section{References}

Central Agency for Public Mobilization and Statistics - Statistical Yearbook - Various Issues, 2019. A questionnaire form for the consumption of red and white meat and fish in Fayoum Governorate.

Nevin Ahmed Hamed (Ph.D.), Yomna Shehata Mostafa (Ph.D.), 2019. An Economic Study of the Production and Consumption of Fattening Chickens in Egypt - The Egyptian Journal of Agricultural Economics, 29(2) June (B).

Hanan Wadih Ghaly (Ph.D.) et al., 2019. An Economic Study of the Possibility of Achieving Selfsufficiency in Animal Protein in Egypt-The Egyptian Journal of Agricultural Economics, 29 (1)March.

Imam Hassab Al-Nabe (Ph.D.), Yassin Eid Abdel Tawab Ahmed (Ph.D.), 2018. An Economic Study of Fish Production and Marketing in Beni Suef Governorate - Egyptian Journal of Agricultural Economics, 28(4) December.

Mashaal, A.A., 2018. An Econometric Study to Estimating the Demand of Meat in Egypt Using the Almost Ideal Demand System (AIDS), J. Agric. Economy and Social Sci., Mansoura Univ., 9 (1): 71-76.

Nagwa M. El-agroudy, Fatima A. Shafiq, Soheir Mokhtar and Monia Bahaa El- Din Hassan, 2019. An Analytical Study of Fish Consumption in Egypt, Middle East J of Agric. Res., 8 (4):1080-1084. 